\author{
Paulina BĘDŹmirowska ${ }^{1}$
}

\title{
Program Rozwoju Obszarów Wiejskich na lata 2014-2020
}

Program Rozwoju Obszarów Wiejskich na lata 2014-2020 (zwany dalej „PROW 2014-2020”) to kolejny, po Planie Rozwoju Obszarów Wiejskich na lata 2004-2006 (zwany dalej „PROW 2004-2006 lub „Plan”) oraz Programie Rozwoju Obszarów Wiejskich na lata 2007-2013 (zwany dalej „PROW 2007-2013”), fundusz współfinansowany ze środków unijnych, realizowany po wejściu Polski do Unii Europejskiej.

Spośród programów realizowanych z funduszy unijnych, zaraz po wstąpieniu do UE ukierunkowanych na rozwój rolnictwa i obszarów wiejskich, w Polsce największy budżet miał Plan Rozwoju Obszarów Wiejskich 2004-2006 współfinansowany z Sekcji Gwarancji Europejskiego Funduszu Orientacji i Gwarancji Rolnej (zwany dalej „EFOiGR”). ${ }^{2}$ Odegrał on znaczącą rolę w przeobrażaniu obszarów wiejskich w Polsce w pierwszych latach po akcesji. Stanowił dokument operacyjny określający cele, priorytety i zadania zrównoważonego rozwoju obszarów wiejskich. Jego celem było wspieranie zrównoważonego rozwoju obszarów wiejskich i polepszenie kondycji gospodarstw rolnych. Był on ukierunkowany na realizację społecznych, ekonomicznych i środowiskowych aspektów rozwoju, spójnie z programami strukturalnymi, zwłaszcza z Sektorowym Programem Operacyjnym „Restrukturyzacja i modernizacja sektora żywnościowego i rozwój obszarów wiejskich" (zwany dalej „SPO Restruktryzacja...”) realizującym cele Narodowego Planu Rozwoju (zwany dalej „NPR”) w zakresie polityki rozwoju obszarów wiejskich. Przygotowany przez Ministerstwo Rolnictwa i Rozwoju Wsi Plan był wdrażany na terenie całego kraju przez Agencję Restrukturyzacji i Modernizacji Rolnictwa jako akredytowaną Agencję Płatniczą i obejmował swoim zasięgiem następujące działania: renty strukturalne, wspieranie gospodarstw niskotowarowych, wspieranie działalności rolniczej na obszarach o niekorzystnych warunkach gospodarowania (zwany dalej „ONW”), wspieranie przedsięwzięć rolnośrodowiskowych i poprawy 
dobrostanu zwierząt, zalesianie gruntów rolnych, dostosowanie gospodarstw rolnych do standardów UE, wspieranie grup producentów rolnych, pomoc techniczna, uzupełnienie płatności obszarowych oraz uzupełnienie środków na realizację Programu SAPARD (w 2004 r.).

Najwięcej środków finansowych Programu przeznaczono na realizację działania „Wspieranie działalności rolniczej na obszarach o niekorzystnych warunkach gospodarowania - ONW" (27\% środków PROW). Na drugim miejscu znalazło się działanie „Dostosowywanie gospodarstw do standardów UE” (17,7\%), a na trzecim „Renty strukturalne” (15,2\%). Znaczną część środków PROW 2004-2006 (20,86\%) przeznaczono na uzupełnienie płatności obszarowych. ${ }^{3}$

Lata 2007-2013 to okres realizacji Programu Rozwoju Obszarów Wiejskich obejmujący dwadzieścia dwa działania w ramach czterech osi priorytetowych finansowanych z Europejskiego Funduszu Rolnego na rzecz Rozwoju Obszarów Wiejskich (13,4 mld euro) oraz współfinansowane z krajowego budżetu (4 mld euro). Dokument określa cele, priorytety i zasady dotyczące korzystania z działań wraz z przewidywanym budżetem przeznaczonym na ich realizację. Na tej podstawie wspierane są finansowo określone działania dotyczące wspierania rozwoju społeczno-ekonomicznego obszarów wiejskich. PROW jest dokumentem przygotowanym zgodnie ze strategicznym podejściem zaproponowanym przez Komisję Europejską. Zgodnie z nim na poziomie unijnym opracowany został dokument strategiczny identyfikujący silne i słabe strony obszarów wiejskich, wspólne dla krajów członkowskich osie priorytetowe oraz wskaźniki dla mierzenia postępu w osiąganiu unijnych priorytetów. W oparciu o strategię UE przygotowywana została strategia krajowa, która realizowana jest przez PROW. Dokumenty podobne do PROW przygotowywane są w każdym z krajów członkowskich UE. Program może odnosić się do terytorium całego kraju (tak jak to ma miejsce w Polsce) lub też przyjmowanych jest wiele różnych programów dla poszczególnych regionów (np. Wielkiej Brytanii). W Polsce PROW posiada cztery tzw. osie priorytetowe, w skład których wchodzą dwadzieścia dwa działania.

Okres realizacji Programu dobiega końca, choć zobowiązania podjęte w trakcie jego trwania trwać będą jeszcze jakiś czas po zakończeniu okresu jego programowania. Należy podkreślić, że największe rezultaty spośród wdrażanych działań w ramach PROW przyniosło działanie „Modernizacja gospodarstw rolnych”. ${ }^{4}$ Do końca $2011 \mathrm{r}$. w ramach tego działania przyznano ponad 40 tys. rolników wsparcie w wysokości 5 miliardów zł, co pozwoli im na realizację inwestycji za około 10 mld zł. Rolnicy kupili m.in. ponad 21 tys. ciągników, przeszło 176 tys. ma- 
szyn i urządzeń rolniczych oraz zrealizowali ponad tysiąc inwestycji budowlanych. ${ }^{5}$ Pieniądze z PROW 2007-2013 unowocześniły też dziesiątki firm zajmujących się przetwórstwem żywności oraz umożliwiły utworzenie na terenach wiejskich blisko 20 tys. nowych miejsc pracy niezwiązanych z rolnictwem. Natomiast młodzi i dobrze wykształceni rolnicy mogli stworzyć, dzięki otrzymanym premiom oraz działaniu „Renty strukturalne”, ok. 20 tys. nowych gospodarstw. Dopłaty z PROW 2007-2013 pozwoliły na utrzymanie opłacalności działalności gospodarczej na terenach trudnych do gospodarowania i górskich (ONW). Gdyby tych dopłat nie było, to z produkcji żywności mogłaby wypaść aż połowa naszego areału rolnego, czyli 7,3 miliona hektarów. Trzeba też zauważyć, że wsparcie z PROW 2007-2013 umożliwiło prowadzenie tradycyjnych upraw i hodowli oraz zapewniło najwyższe standardy ochrony środowiska na obszarze ok. 2,3 mln hektarów, a także pozwoliło na zalesienie ok. 62 tys. hektarów najgorszych gruntów. Z kolei firmom zajmującym się przetwórstwem żywności wypłacono ponad 1,1 mld zł i dzięki temu mogły one zainwestować w modernizację i rozwój swoich zakładów blisko 3 mld zł i obecnie należą do najszybciej rozwijających się w Polsce wytwarzając ponad 15 proc. całej produkcji przemysłowej.

Nowy zarys polityki wiejskiej na lata 2014-2020 został określony w komunikacie Komisji z 18 listopada 2010 r. do Parlamentu Europejskiego, Rady, Europejskiego Komitetu Ekonomiczno-Społecznego i Komitetu Regionów pt. „Wspólna polityka rolna do 2020: sprostać wymaganiom przyszłości związanym z żywnością, zasobami naturalnymi i aspektami terytorialnymi”" oraz w Komunikacie Komisji pt. „Europa 2020. Strategia na rzecz inteligentnego i zrównoważonego rozwoju sprzyjającego włączeniu społecznemu". ${ }^{7} \mathrm{Na}$ tej podstawie Komisja przygotowała obszerny pakiet projektów aktów legislacyjnych dotyczących m.in. wspierania rozwoju obszarów wiejskich. ${ }^{8}$

W dniach 7 i 8 lutego 2013 r., na posiedzeniach Rady Europejskiej, a także na posiedzeniach Rady Ministrów Rolnictwa w dniach 18 i 19 marca 2013 r. w Brukseli odbył się szczyt Unii Europejskiej, podczas którego dyskutowano założenia nowego okresu programowania i ustalono, że Polska będzie największym beneficjentem unijnych funduszy. ${ }^{9} \mathrm{Z}$ ogółu funduszy spójności na wyrównywanie poziomu rozwoju między krajami i regionami UE Polska otrzyma wsparcie w wysokości $23 \%$ środków budżetu UE, co oznacza, że na polskie rolnictwo przeznaczone zostały $32 \mathrm{mld}$

5 Źródło: ARiMR, www.arimr.gov.pl, dane na dzień 31.12.2012 r.

6 COM /2010/672 wersja ostateczna.

7 COM /2010/2020 wersja ostateczna, Bruksela 03.03.2010 r.

8 Zob. wniosek Komisji: Rozporządzenie Parlamentu Europejskiego i Rady w sprawie wsparcia rozwoju obszarów wiejskich przez Europejski Fundusz Rolny na rzecz Rozwoju Obszarów Wiejskich (EFRROW); COM/2011/0627. Za: E. Tomkiewicz, M. Bocheński, Polityka rozwoju obszarów wiejskich w perspektywie lat 2014-2020 w kontekście nowych wyzwań, „Studia luridica Agraria” 2012, tom X. 
euro (tj. 133,4 mld zł) przez siedem lat. ${ }^{10}$ Do najważniejszych postanowień kompromisu na Radzie UE ds. Rolnictwa i Rybołówstwa WPR na lata 2014-2020 dla Polski w ramach wsparcia rozwoju obszarów wiejskich z EFRROW należy zaliczyć fakt, że 25\% limitu środków EFRROW na działania prośrodowiskowe obejmuje: płatności ONW, rolnośrodowiskowe, na rolnictwo ekologiczne, płatności dla NATURA 2000, płatności do zalesień oraz inwestycje o pozytywnych efektach środowiskowych. Ponadto za sukces należy uznać, że w województwie mazowieckim utrzymano $50 \%$ poziom dofinansowania inwestycji, a także dopuszczono, bez konsekwencji finansowych dla rolników, możliwości opóźnienia do 2016 r. wejścia w życie reformy wyznaczenia nowego ONW. ${ }^{11}$

W dniu 17 kwietnia 2013 r., na posiedzeniu Sejmowej Komisji ds. Rolnictwa i Rozwoju Wsi, zaprezentowane zostały konsultacje krajowe dotyczące założeń do PROW 2014-2020. W dniu 23 kwietnia 2013 r. odbyło się pierwsze posiedzenie Grupy Roboczej wspierającej prace nad przygotowaniem programu rozwoju obszarów wiejskich na lata 2014-2020, w trakcie którego przedstawiono i przedyskutowano Wstępny zarys Programu Rozwoju Obszarów Wiejskich na lata 2014-2020 ${ }^{12}$ (zwany dalej „wstępnym zarysem”). Zgodnie z tym dokumentem, w perspektywie finansowej, w latach 2014-2020, publiczne wsparcie finansowe adresowane do polskiego rolnictwa i obszarów wiejskich ukierunkowane będzie na realizację celów określonych w Strategii zrównoważonego rozwoju wsi, rolnictwa i rybactwa ${ }^{13}$ oraz celów sformułowanych w dokumentach wspólnotowych odnoszących się do polityki rozwoju obszarów wiejskich. ${ }^{14}$

Strategia jest jednym z dziewięciu dokumentów strategicznych o charakterze sektorowym w ramach obowiązującego w Polsce systemu zarządzania rozwojem. W perspektywie 2020 roku, zawarty w niej cel ogólny rozwoju obszarów wiejskich, rolnictwa i rybactwa w Polsce został sformułowany następująco: ,poprawa jakości życia na obszarach wiejskich oraz efektywne wykorzystanie ich zasobów i potencjałów, w tym rolnictwa i rybactwa, dla zrównoważonego rozwoju kraju”.

Strategia wyznacza także pięć celów szczegółowych dla działań w zakresie rozwoju obszarów wiejskich, rolnictwa i rybactwa w perspektywie do 2020 roku, do których należą:

1. Wzrost jakości kapitału ludzkiego, społecznego, zatrudnienia i przedsiębiorczości na obszarach wiejskich,

Dokument dostępny na stronie Ministerstwa Rolnictwa i Rozwoju Wsi, http://www.minrol.gov.pl/pol/Wsparcie-rolnictwa-i-rybolowstwa/PROW-2014-2020

Uchwała nr 163 Rady Ministrów z dnia 25 kwietnia 2012 r. w sprawie przyjęcia „Strategii zrównoważonego rozwoju wsi, rolnictwa i rybactwa” na lata 2012-2020, Monitor Polski z 9 listopada 2012 r., poz. 839.

W szczególności projekt Rozporządzenia Parlamentu i Rady w sprawie wsparcia rozwoju obszarów wiejskich przez Europejski Fundusz Rolny na rzecz Rozwoju Obszarów Wiejskich (EFRROW). 
2. Poprawa warunków życia na obszarach wiejskich oraz poprawa ich dostępności przestrzennej,

3. Bezpieczeństwo żywnościowe,

4. Wzrost produktywności i konkurencyjności sektora rolno-spożywczego,

5. Ochrona środowiska i adaptacja do zmian klimatu na obszarach wiejskich.

Możliwość realizacji części z wyżej wymienionych celów Strategii stwarza Wspólna Polityka Rolna (w tym jej II filar). Natomiast część celów rozwojowych wskazanych w Strategii będzie realizowana w ramach innych polityk rozwoju kraju i z wykorzystaniem różnych źródeł finansowania, w tym przy współfinansowaniu z Europejskiego Funduszu Morskiego i Rybackiego, Europejskiego Funduszu Rozwoju Regionalnego i Europejskiego Funduszu Społecznego.

Program Rozwoju Obszarów Wiejskich na lata 2014-2020 stanowić będzie jeden z najważniejszych narzędzi realizacji ww. Strategii ${ }^{15}$ realizując cel ogólny i te jej cele szczegółowe, które odpowiadają misji i celom Wspólnej Polityki Rolnej oraz unijnym priorytetom rozwoju obszarów wiejskich.

W oparciu o propozycje i uwagi zgłoszone w ramach szerokich konsultacji społecznych do Wstępnego Zarysu PROW 2014-2020 pod koniec lipca 2013 r. opracowany został Projekt PROW 2014-2020 (zwany dalej „Projektem”), który opublikowano na stronach internetowych MRiRW i Krajowej Sieci Obszarów Wiejskich.

Mając na względzie konieczność precyzyjnego zdiagnozowania potrzeb wsi, rolnictwa i przetwórstwa rolno-spożywczego oraz wyzwań, jakie stoją przed producentami rolnymi, mieszkańcami wsi i przedsiębiorcami w Polsce, opracowywany Program podlega szerokim konsultacjom społecznym. Podstawowym narzędziem procesu konsultacji społecznych PROW 2014-2020 jest powołany przez Ministra Rolnictwa i Rozwoju Wsi specjalny organ opiniodawczo-doradczy, tj. zespół wspierający prace nad przygotowaniem programu rozwoju obszarów wiejskich na lata 2014-2020. Przedstawiciele rolników, organizacji społecznych i gospodarczych oraz samorządów, uczestniczący w pracach zespołu zgłosili w czasie pierwszego etapu konsultacji szereg propozycji i komentarzy do prezentowanych dokumentów. Równolegle z pracami zespołu prowadzone były także konsultacje online poprzez stronę internetową Ministerstwa Rolnictwa i Rozwoju Wsi oraz Krajowej Sieci Obszarów Wiejskich. ${ }^{16}$ Odbyło się też wiele spotkań i konferencji prezentujących założenia nowego programu, podczas których wszyscy zainteresowani mogli zgłaszać swoje postulaty i komentarze. Zebrane w ramach pierwszego etapu kon-

15 Drugim ważnym narzędziem realizacji tej Strategii będzie program operacyjny dotyczący obszarów morskich i rybackich.

16 Informacja o przebiegu prac nad Programem Rozwoju Obszarów Wiejskich na lata 2014-2020, Biuletyn KSOW, lato 2/2013. 
sultacji uwagi, w tym zgłoszenia pisemne, zostały przeanalizowane i wykorzystane w pracach nad I wersją Projektu PROW 2014-2020. Podobnie przebiegał drugi etap konsultacji nad I wersją Projektu PROW 2014-2020 i został zakończony 15 września 2013 r. ${ }^{17}$

Zgodnie z założeniami, PROW 2014-2020 stanowił będzie kontynuację i rozwinięcie kierunków wsparcia realizowanych w okresie po przystąpieniu Polski do Unii Europejskiej i ukierunkowany będzie szczególnie na kwestie związane z budową konkurencyjności rolnictwa, które jest dziedziną szczególnie istotną z punktu widzenia rozwoju obszarów wiejskich, a zarazem, z racji problemów strukturalnych i wyzwań rozwojowych, wymaga znacznego i odpowiednio ukierunkowanego wsparcia.

Opracowywanie PROW 2014-2020 odbywa się zgodnie z przepisami unijnymi, w szczególności z rozporządzeniem Parlamentu Europejskiego i Rady ustanawiającym wspólne przepisy dotyczące Europejskiego Funduszu Regionalnego, Europejskiego Funduszu Społecznego, Funduszu Spójności, Europejskiego Funduszu Rolnego na rzecz Rozwoju Obszarów Wiejskich oraz Europejskiego Funduszu Morskiego i Rybackiego objętych zakresem wspólnych ram strategicznych oraz ustanawiającym przepisy ogólne dotyczące Europejskiego Funduszu Rozwoju Regionalnego, Europejskiego Funduszu Społecznego i Funduszu Spójności oraz uchylającym rozporządzenie (WE) nr 1083/2006 ${ }^{18}$ i rozporządzeniem Parlamentu Europejskiego i Rady w sprawie wsparcia rozwoju obszarów wiejskich przez Europejski Fundusz Rolny na rzecz Rozwoju Obszarów Wiejskich (EFRROW) ${ }^{19}$ które określa podstawy dla realizacji w państwach członkowskich UE zreformowanego wsparcia rozwoju obszarów wiejskich.

Projektowane przepisy UE przewidują wkomponowanie programów rozwoju obszarów wiejskich w całościowy system polityki rozwoju, w szczególności poprzez mechanizm Umowy Partnerstwa. Umowa ta określa strategię wykorzystania środków unijnych na rzecz realizacji wspólnych dla UE celów określonych w unijnej strategii wzrostu „Europa 2020 - Strategia na rzecz inteligentnego i zrównoważonego rozwoju sprzyjającego włączeniu społecznemu" ${ }^{20} \mathrm{z}$ uwzględnieniem potrzeb rozwojowych danego państwa członkowskiego. ${ }^{21}$ Jako element Wspólnej Polityki Rolnej, polityka rozwoju obszarów wiejskich ma wspierać konkurencyjność rolnictwa, zrównoważone wykorzystanie zasobów naturalnych, w tym działania na rzecz

17 Europejski Fundusz Rolny na rzecz Rozwoju Obszarów Wiejskich: Europa inwestująca w obszary wiejskie, Ministerstwo Rolnictwa i Rozwoju Wsi, www.minrol.gov.pl $\operatorname{COM}(2013) 246$ wersja ostateczna.

Rozporządzenie Rady (WE) nr 1698/2005, z dnia 20 września 2005 r., Dziennik Urzędowy L 277, 21/10/2005. Komunikat Komisji Europejskiej z dnia 3 marca 2010 r. zatytułowany „Europa 2020: Strategia na rzecz inteligentnego i zrównoważonego rozwoju sprzyjającego włączeniu społecznemu” [COM(2010) 2020]. 21 Projekt Programu Rozwoju Obszarów Wiejskich 2014-2020, wersja I, Ministerstwo Rolnictwa i Rozwoju Wsi, 26
lipca 2013 r., s. 7. 
klimatu oraz zrównoważony rozwój terytorialny obszarów wiejskich. Poprzez włączenie we Wspólne Ramy Strategiczne i Umowę Partnerską, realizacja polityki rozwoju obszarów wiejskich będzie ściśle powiązana z polityką spójności.

Celem Programu Rozwoju Obszarów Wiejskich na lata 2014-2020 będzie poprawa konkurencyjności rolnictwa, zrównoważone zarządzanie zasobami naturalnymi i działania w dziedzinie klimatu oraz zrównoważony rozwój terytorialny obszarów wiejskich. Ich realizacja odbywać się będzie zgodnie z priorytetami wyznaczonymi dla wspólnotowej polityki rozwoju obszarów wiejskich na lata 20142020, do których należą 22:

1. Ułatwianie transferu wiedzy i innowacji w rolnictwie, leśnictwie i na obszarach wiejskich;

2. Poprawa konkurencyjności wszystkich sektorów rolnictwa i zwiększenie rentowności gospodarstw rolnych;

3. Poprawa organizacji łańcucha żywnościowego i promowanie zarządzania ryzykiem w rolnictwie;

4. Odtwarzanie, chronienie i wzmacnianie ekosystemów zależnych od rolnictwa i leśnictwa;

5. Wspieranie efektywnego gospodarowania zasobami i przechodzenia na gospodarkę niskoemisyjną i odporną na zmianę klimatu w sektorach rolnym, spożywczym i leśnym;

6. Zwiększenie włączenia społecznego, ograniczanie ubóstwa i promowanie rozwoju gospodarczego na obszarach wiejskich.

Zgodnie z Projektem PROW 2014-2020, ${ }^{23} \mathrm{w}$ ramach powyższych priorytetów realizowane będą poszczególne cele szczegółowe, tj.:

\begin{tabular}{|l|l||}
\hline \multicolumn{1}{|c|}{ Priorytet } & \multicolumn{1}{c|}{ Cele szczegółowe } \\
\hline $\begin{array}{l}\text { 1. Ułatwianie transferu wiedzy i innowacji w rolnictwie, le- } \\
\text { śnictwie i na obszarach wiejskich }\end{array}$ & $\begin{array}{l}\text { (1a) Zwiększenie innowacyjności i bazy wiedzy na ob- } \\
\text { szarach wiejskich, } \\
\text { (1b)Wzmocnienie powiązań między rolnictwem i leśnic- } \\
\text { twem a badaniami i innowacją, } \\
\text { (1c) Promowanie uczenia się przez całe życie oraz szko- } \\
\text { lenia zawodowego w sektorach roślinnym i leśnym. }\end{array}$ \\
\hline $\begin{array}{l}\text { 2. Poprawa konkurencyjności wszystkich sektorów rolnic- } \\
\text { twa i zwiększenie rentowności gospodarstw rolnych }\end{array}$ & $\begin{array}{l}\text { (2a) Ułatwianie restrukturyzacji gospodarstw rolnych } \\
\text { n niskim poziomie uczestnictwa rynku, gospodarstw rol- } \\
\text { w określonych sektorach i gospodarstw wymagających } \\
\text { zróżnicowania produkcji rolnej, } \\
\text { (2b) Ułatwienie wymiany pokolen w sektorze rolnym. }\end{array}$ \\
\hline
\end{tabular}

23 Projekt Programu Rozwoju Obszarów Wiejskich 2014-2020, wersja I, Ministerstwo Rolnictwa i Rozwoju Wsi, 26 lipca 2013 r. 


\begin{tabular}{|c|c|}
\hline $\begin{array}{l}\text { 3. Poprawa organizacji łańcucha żywnościowego i pro- } \\
\text { mowanie zarządzania ryzykiem w rolnictwie }\end{array}$ & $\begin{array}{l}\text { (3a) Lepsze zintegrowanie głównych producentów z łań- } \\
\text { cuchem żywnościowym poprzez systemy jakości, promo- } \\
\text { cję na rynkach lokalnych, krótkie cykle dostaw, grupy pro- } \\
\text { ducentów i organizacje międzybranżowe, } \\
\text { (3b) Wspieranie zarządzania ryzykiem w gospodar- } \\
\text { stwach rolnych. }\end{array}$ \\
\hline $\begin{array}{l}\text { 4. Odtwarzanie, chronienie i wzmacnianie ekosystemów } \\
\text { zależnych od rolnictwa i leśnictwa }\end{array}$ & $\begin{array}{l}\text { (4a) Odtwarzanie i zachowanie różnorodności biolo- } \\
\text { gicznej, w tym na obszarach Natura } 2000 \text { oraz rolnictwa } \\
\text { o wysokiej jakości przyrodniczej i stanu europejskich kra- } \\
\text { jobrazów, } \\
\text { (4b) Poprawa gospodarki wodnej, } \\
\text { (4c) Poprawa gospodarowania glebą. }\end{array}$ \\
\hline $\begin{array}{l}\text { 5. Wspieranie efektywnego gospodarowania zasobami } \\
\text { i przechodzenia na gospodarkę niskoemisyjną i odpor- } \\
\text { ną na zmianę klimatu w sektorach rolnym, spożywczym } \\
\text { i leśnym }\end{array}$ & $\begin{array}{l}\text { (5a) Poprawa efektywności korzystania z zasobów wod- } \\
\text { nych w rolnictwie, } \\
\text { (5b) Poprawa efektywności korzystania z ener- } \\
\text { gii w rolnictwie i przetwórstwie spożywczym, } \\
\text { (5c) Ułatwianie dostaw i wykorzystywania odnawialnych } \\
\text { źródeł energii produktów ubocznych, odpadów, pozosta- } \\
\text { łości i innych surowców nieżywnościowych dla celów bio- } \\
\text { gospodarki, } \\
\text { (5d) Redukcja emisji podtlenku azotu i metanu z rolnic- } \\
\text { twa, } \\
\text { (5e) Zwiększenie sekwestracji węgla w rolnictwie i leśnic- } \\
\text { twie. }\end{array}$ \\
\hline $\begin{array}{l}\text { 6. Zwiększenie włączenia społecznego, ograniczanie } \\
\text { ubóstwa i promowanie rozwoju gospodarczego na ob- } \\
\text { szarach wiejskich }\end{array}$ & $\begin{array}{l}\text { (6a) Ułatwianie różnicowania działalności, zakładania no- } \\
\text { wych małych przedsiębiorstw i tworzenie miejsc pracy, } \\
\text { (6b) Wspieranie lokalnego rozwoju na obszarach wiej- } \\
\text { skich." }\end{array}$ \\
\hline
\end{tabular}

* Pominięto ujęty w projekcie rozporzadzenia EFRROW cel szczegótowy (6c) Wsparcie dostęu do technologii ICT i ich wykorzystania na obszarach wiejskich. Nie będzie on realizowany ze środków EFRROW - catość zadań z tego zakresu uwzględniona zostanie w polityce spójności.

Wstępny opis działań proponowanych w Projekcie PROW na lata 2014-2020 zakłada istnienie w jego ramach następujących działań:

- ,Transfer wiedzy” (art. 15),

- „Doradztwo” (art. 16),

- „Systemy jakości produktów rolnych i środków spożywczych” (art. 17),

- „Modernizacja gospodarstw rolnych” (art. 18.1.a),

- „Przetwórstwo i marketing produktów rolnych” (art. 18.1.b),

- „Scalanie gruntów” (art. 18.1.c),

- „Przywracanie potencjału produkcji rolnej zniszczonego w wyniku klęsk żywiołowych i katastrof oraz wprowadzanie odpowiednich działań zapobiegawczych" (art. 19),

- „Premia dla młodych rolników” (art. 20.1.a.i),

- „Restrukturyzacja małych gospodarstw” (art. 20. 1 a iii),

- „Premie na rozpoczęcie działalności pozarolniczej” (art. 20.1.a.ii),

- „Podstawowe usługi i odnowa wsi na obszarach wiejskich” (art. 21), 
- „Zalesianie i tworzenie terenu zalesionego" - art. 22.1.a (art. 23),

- „Tworzenie grup producentów” (art. 28),

- „Program rolnośrodowiskowo-klimatyczny” (art. 29),

- „Rolnictwo ekologiczne” (art. 30),

- „Płatności dla obszarów ONW” (art. 32),

- „Współpraca” (art. 36),

- Działania „LEADER” (art. 42-45).

PROW 2014-2020 przygotowany będzie na poziomie centralnym przez Ministra jako Instytucję Zarządzającą (IZ) i współfinansowany głównie w oparciu o środki budżetu państwa. Rolę agencji płatniczej pełni Agencja Restrukturyzacji i Modernizacji Rolnictwa (ARiMR) na podstawie uzyskanej akredytacji. Zakłada się, ${ }^{24}$ że działania Programu wdrażane będą przez Agencję Restrukturyzacji i Modernizacji Rolnictwa, Agencję Rynku Rolnego, Fundację Programów Pomocy dla Rolnictwa i samorządy województw. Ponadto, rolę jednostki centralnej w ramach Krajowej Sieci Obszarów Wiejskich pełnić będzie Krajowe Centrum Doradztwa Rolniczego w Brwinowie.

Z uwagi na znaczne różnice w poziomie i potrzebach rozwojowych obszarów wiejskich i rolnictwa w poszczególnych regionach Polski, Projekt PROW 20142020 zakłada wdrożenie odpowiednich mechanizmów dostosowujących zakres i warunki wsparcia udzielanego w ramach Programu do specyfiki poszczególnych województw. Z kolei niektóre instrumenty wsparcia funkcjonować muszą w sposób niezależny od podziału administracyjnego kraju, jak np. płatności dla rolników gospodarujących na obszarach z ograniczeniami naturalnymi lub innymi szczególnymi ograniczeniami (ONW) lub płatności Natura $2000 .{ }^{25} \mathrm{Z}$ uwagi na to, w odniesieniu do niektórych instrumentów wsparcia inwestycyjnego ważne jest dostosowanie zakresu ich stosowania do uwarunkowań i potrzeb regionalnych. Równie istotne jest przy tym zapewnienie zrównoważonego w skali kraju dostępu do środków i tym samym zapobieżenie pogłębianiu się dysproporcji rozwojowych między regionami.

Mając na względzie powyższe, Projekt PROW 2014-2020 zakłada zastosowanie tzw. pogłębionej regionalizacji Programu. Mechanizm ten polegał będzie na dokonaniu podziału części całkowitego budżetu programu ${ }^{26}$ na pule przeznaczone dla poszczególnych województw, a następnie określenie przez Samorządy Województw, które z działań i w jakim wymiarze finansowym powinny zostać wdrożone

24 Projekt Programu Rozwoju Obszarów Wiejskich 2014-2020, wersja I, Ministerstwo Rolnictwa i Rozwoju Wsi, 26 lipca 2013 r., s. 197.

Do 2018 r. państwa członkowskie są zobowiązane do wyznaczenia obszarów o ograniczeniach naturalnych (obecnie ONW) w oparciu o osiem nowych kryteriów biofizycznych, jakie zaproponowała Komisja. 
na ich terenie. W związku z powyższym, ostateczny budżet poszczególnych działań zostanie określony na podstawie wskazań poszczególnych województw.

Kolejnym projektowanym mechanizmem pogłębionej regionalizacji jest zróżnicowanie kryteriów dostępu lub wyboru operacji w ramach niektórych działań Programu poprzez odmienne w różnych województwach określenie grup docelowych odbiorców pomocy lub preferowanych obszarów, sektorów, co pozwoli dostosować poszczególne instrumenty wsparcia do specyfiki poszczególnych województw.

Na nowy okres programowania, tj. lata 2014-2020, w polityce rozwoju obszarów wiejskich utrzymano dotychczasowe podejście, dające państwom członkowskim autonomię w kształtowaniu programów rozwoju obszarów wiejskich w oparciu o pewien katalog działań. Należy przy tym podkreślić, że nowe przepisy dotyczące drugiego filara będą bardziej elastyczne - państwa członkowskie będą decydować, jakie działania zastosować, aby osiągnąć cele ustanowione na bazie sześciu priorytetów rozwoju obszarów wiejskich oraz podpriorytetów. ${ }^{27}$ Polityka rozwoju obszarów wiejskich prowadzona będzie w ścisłej koordynacji z innymi politykami rozwojowymi za pośrednictwem unijnych wspólnych ram strategicznych oraz umowy o partnerstwie zawieranej na poziomie krajowym, obejmującej wszelkie rodzaje wsparcia z europejskich funduszy strukturalnych i inwestycyjnych (EFROW, EFRR, Fundusz Spójności, EFS i EFMR w danym państwie członkowskim).

Ponadto, państwa członkowskie otrzymały możliwość opracowania tematycznych podprogramów, ukierunkowanych na młodych rolników, niewielkie gospodarstwa rolne, obszary górskie, kobiety na obszarach wiejskich, czy też związanych z łagodzeniem skutków zmiany klimatu dostosowania się do nich, różnorodnością biologiczną oraz krótkimi lańcuchami dostaw. W ramach niektórych podprogramów dostępne będą wyższe poziomy wsparcia.

Warto podkreślić, że Projekt PROW 2014-2020 zakłada utrzymanie działań ukierunkowanych na restrukturyzację, inwestycje i modernizację w rolnictwie, a także wsparcie dla młodych rolników i małych gospodarstw, wsparcie dywersyfikacji działalności gospodarczej, odnowy wsi i usług podstawowych. Innowacje stanowić mają motyw przewodni w działaniach związanych $\mathrm{z}$ transferem wiedzy, współpracą i inwestycjami w środki trwałe, z kolei rolnictwo ekologiczne stanowić będzie odrębne działanie. Ponadto, do katalogu PROW wprowadzono zestaw działań związanych z zarządzaniem ryzykiem: ubezpieczenia i fundusze wzajemne oraz instrument stabilizacji dochodów. Na działanie LEADER państwa członkowskie będą musiały przeznaczyć 5\% swojej koperty I filara. W podejściu tym możli- 
we będzie wykorzystanie środków z innych funduszy rozwojowych UE (fundusze polityki spójności i fundusz „,rybacki”). ${ }^{28}$

Bardzo ważny element reformy stanowi poszerzenie zakresu działań związanych z celami środowiskowo-klimatycznymi, które wypełniają minimalny próg alokacji wydatków EFRROW, ustalony na poziomie 30\%. Obejmuje on: rolnictwo ekologiczne, działania rolnośrodowiskowo-klimatyczne, wsparcie dla obszarów z ograniczeniami naturalnymi i innymi szczególnymi ograniczeniami, inwestycje w środki trwałe o pozytywnych efektach środowiskowo-klimatycznych, grupę działań „leśnych” oraz płatności dla obszarów Natura 2000. ${ }^{29}$

W ramach kompromisu uwzględniono także możliwości wsparcia przetwórstwa rolno-spożywczego w priorytecie dotyczącym poprawy funkcjonowania łańcucha żywnościowego oraz rozszerzono zakres wsparcia w ramach działania „Systemy jakości żywności” o wsparcie działań informacyjno-promocyjnych realizowanych przez grupy producentów rolnych.

Ważnym elementem PROW 2014-2020 będzie ukierunkowanie niektórych działań II filara wyłącznie na aktywnych rolników, zgodnie z definicją stosowaną dla płatności bezpośrednich. Ma to dotyczyć rolnictwa ekologicznego, płatności dla obszarów z ograniczeniami naturalnymi i innymi szczególnymi ograniczeniami, płatności dla młodego rolnika, płatności w ramach systemów jakości żywości, płatności w ramach zarządzania ryzykiem oraz działania dobrostan zwierząt, przy czym w ramach wsparcia dla młodych rolników umożliwiono uzyskanie statusu aktywnego rolnika w ciągu osiemnastu miesięcy od podjęcia działalności. ${ }^{30}$

Należy mieć na uwadze, że przedstawione założenia Programu Rozwoju Obszarów Wiejskich 2014-2020 mają charakter wstępny i podlegać będą nadal uzgodnieniom. Zgodnie ze wspólnotową zasadą partnerstwa w proces opracowania Programu zaangażowani są partnerzy gospodarczy i społeczni, podmioty reprezentujące społeczeństwo obywatelskie, w tym partnerzy działający na rzecz ochrony środowiska, organizacje pozarządowe oraz podmioty odpowiedzialne za promowanie równości i niedyskryminacji, którym zapewniono uczestnictwo w procesie kształtowania mechanizmów pomocowych planowanych w ramach PROW 2014-2020.

Obecnie wszystkie zgłoszone w drugim etapie konsultacji uwagi są analizowane i wykorzystywane do prac nad kolejną, pełną wersją programu. Planuje się, że po zakończeniu tych prac i ostatecznym ustaleniu budżetu Programu, dokument programowy zostanie przekazany do konsultacji w ramach trzeciego etapu konsultacji społecznych PROW 2014-2020, zamykających proces konsultacji Programu w Pol- 
sce. Po zakończeniu konsultacji i opracowaniu PROW 2014-2020, dokument zostanie przedłożony do rozpatrzenia Radzie Ministrów. Następnie, po jej akceptacji, Program zostanie przesłany do akceptacji Komisji Europejskiej.

Tabela 1. Wydatki na rozwój obszarów wiejskich w programach zrealizowanych w okresie 2002-2008 (zgodnie z zasadą "n+2” realizowaną do 2008 r.) ${ }^{31}$

\begin{tabular}{|l|c|c|}
\hline \multicolumn{1}{|c|}{ Program } & $\begin{array}{c}\text { Środki ogółem } \\
(\mathrm{mld} \mathrm{zł)}\end{array}$ & $\begin{array}{c}\text { Udział } \\
\text { procentowy }\end{array}$ \\
\hline SAPARD ${ }^{* *}$ & 4,5 & $17,4 \%$ \\
\hline PROW 2004-06** & 13,7 & $53,3 \%$ \\
\hline SPO „Restrukturyzacja... & 6,8 & $26,3 \%$ \\
\hline ZPORR na obszary wiejskie ${ }^{*+* *}$ & 0,8 & $3,1 \%$ \\
\hline Razem & 25,8 & $100,0 \%$ \\
\hline
\end{tabular}

* Dane szacunkowe uzależnione od stosowanego kursu euro

** Wraz ze środkami z PROW 2004-2006

*** Bez wydatków na projekty SAPARD

**** Dane szacunkowe

Źródto: wyliczenia własne DROW MRiRW na podstawie danych ARiMR i MRR (działanie 3.1 ZPORR). 
THE RURAL DEVELOPMENT PROGRAMME FOR 2014-2020

Key words: rural development program, development of rural areas, new programming period

The aim of the article is to present the Rural Development Program 2014-2020 as a new fund to support rural development in Poland.

The Rural Development Programme for the period of 2014 until 2020 constitutes yet another, following the Rural Development Plan for 2004-2006 and the Rural Development Programme 2007-2013, fund financed by the EU, which has been established after Polish accession to the European Union. According to the assumptions, the RDP 2014-2020 will constitute a continuation and development of such directions of support as have been followed since Poland's accession to the European Union, and will be particularly focused on issues related to the advancement of the competitiveness of agriculture, which issues are of particular importance from the point of view of the development of rural areas; moreover, due to structural problems and development challenges, the very advancement requires substantial and well-targeted support.

The purpose of the Rural Development Programme for 2014-2020 is to improve the competitiveness of agriculture, and also to facilitate sustainable management of natural resources and climate action and balanced territorial development of rural areas. 